OPEN ACCESS

Edited by:

Sven Bilke,

National Institutes of Health, USA

Reviewed by:

Parvin Mehdipour,

Tehran University of Medical

Sciences, Iran

Ann M. Moyer,

Mayo Clinic, USA

Jihyoun Lee,

Soonchunhyang University Hospital,

South Korea

*Correspondence: Henry Lynch

htlynch@creighton.edu;

San Ming Wang

sanming.wang@unmc.edu

Specialty section: This article was submitted to Cancer

Genetics,

a section of the journal

Frontiers in Oncology

Received: 04 January 2016 Accepted: 29 March 2016

Published: 13 April 2016

Citation:

Cui J, Luo J, Kim YC, Snyder C, Becirovic D, Downs B, Lynch H and

Wang SM (2016) Differences of Variable Number Tandem Repeats in XRCC5 Promoter Are Associated with Increased or Decreased Risk of Breast Cancer in BRCA Gene Mutation Carriers. Front. Oncol. 6:92. doi: 10.3389/fonc.2016.00092

\section{Differences of Variable Number Tandem Repeats in XRCC5 Promoter Are Associated with Increased or Decreased Risk of Breast Cancer in BRCA Gene Mutation Carriers}

\author{
Jian Cui', Jiangtao Luo ${ }^{2}$, Yeong C. Kim ${ }^{1}$, Carrie Snyder ${ }^{3}$, Dina Becirovic ${ }^{3}$, \\ Bradley Downs ${ }^{1}$, Henry Lynch ${ }^{3 *}$ and San Ming Wang ${ }^{1 *}$
}

${ }^{1}$ Department of Genetics, Cell Biology and Anatomy, College of Medicine, University of Nebraska Medical Center, Omaha, NE, USA, ${ }^{2}$ Department of Biostatistics, College of Public Health, University of Nebraska Medical Center, Omaha, NE, USA, ${ }^{3}$ Department of Preventive Medicine, Hereditary Cancer Center, Creighton University, Omaha, NE, USA

Ku80 is a subunit of the Ku heterodimer that binds to DNA double-strand break ends as part of the non-homologous end joining (NHEJ) pathway. Ku80 is also involved in homologous recombination (HR) via its interaction with BRCA1. Ku80 is encoded by the XRCC5 gene that contains a variable number tandem repeat (VNTR) insertion in its promoter region. Different VNTR genotypes can alter XRCC5 expression and affect Ku80 production, thereby affecting NHEJ and HR pathways. VNTR polymorphism is associated with multiple types of sporadic cancer. In this study, we investigated its potential association with familial breast cancer at the germline level. Using PCR, PAGE, Sanger sequencing, and statistical analyses, we compared VNTR genotypes in the XRCC5 promoter between healthy individuals and three types of familial breast cancer cases: mutated BRCA1 (BRCA1+), mutated BRCA2 (BRCA2+), and wild-type BRCA1/BRCA2 (BRCAx). We observed significant differences of VNTR genotypes between control and $B R C A 1^{+}$ group $(P<0.0001)$ and $B R C A 2^{+}$group $(P=0.0042)$ but not $B R C A x$ group $(P=0.2185)$, and the differences were significant between control and cancer-affected $B R C A 1^{+}$cases $(P<0.0001)$ and $B R C A 2^{+}$cases $(P=0.0092)$ but not cancer-affected $B R C A x$ cases $(P=0.4251)$. Further analysis indicated that $2 \mathrm{R} / 2 \mathrm{R}(\mathrm{OR}=1.94,95 \% \mathrm{Cl}=1.26-2.95$, $P=0.0096)$ and $2 \mathrm{R} / 1 \mathrm{R}(\mathrm{OR}=1.58,95 \% \mathrm{Cl}=1.11-2.26, P=0.0388)$ were associated with increased risk but $1 \mathrm{R} / 1 \mathrm{R}(\mathrm{OR}=0.55,95 \% \mathrm{Cl}=0.35-0.84, P=0.0196)$ and $1 \mathrm{R} / \mathrm{OR}(\mathrm{OR}=0,95 \% \mathrm{Cl}=0-0.29, P=0.0012)$ were associated with decreased risk in cancer-affected $B R C A 1^{+}$group; $2 \mathrm{R} / 1 \mathrm{R}(\mathrm{OR}=1.94,95 \% \mathrm{Cl}=1.14-3.32, P=0.0242)$ was associated with increased risk in cancer-affected $B R C A 2^{+}$group. No correlation was observed for the altered risk between cancer-affected or -unaffected carriers and between different age of cancer diagnosis in cancer-affected carriers. The frequently

\footnotetext{
Abbreviations: $B R C A 1$, breast cancer 1, early onset; $B R C A 2$, breast cancer 2, early onset; $B R C A x$, familial breast cancer with wild type $B R C A 1$ and $B R C A 2$; HR, homologous recombination; NHEJ, non-homologous end joining; PAGE, polyacrylamide gel electrophoresis; VNTR, variable number tandem repeat.
} 
observed VNTR association with in $B R C A 1^{+}$and $B R C A 2^{+}$breast cancer group indicates that VNTR polymorphism in the XRCC5 promoter is associated with altered risk of breast cancer in $B R C A 1^{+}$and $B R C A 2^{+}$carriers.

Keywords: Ku80, XRCC5, promoter, VNTR, familial breast cancer, BRCA1, BRCA2, association

\section{INTRODUCTION}

Breast cancer is the major cancer type in women. Up to $20 \%$ of breast cancer cases have familial genetic background, with multiple family members across generations affected by the disease (1). The discovery of the germline mutations in BRCA1 and BRCA2 confirmed the presence of genetic predisposition for familial breast cancer (2-4). These genes maintain genome stability in normal cells by repairing double-strand breaks mainly through homologous recombination (HR) pathway; their mutated forms lead to genome instability and increased risk for breast cancer development (5). There are two types of DNA double-strand break repair mechanisms: non-homologous end joining (NHEJ) and HR (6). Deficiency in the HR pathway, mainly caused by $B R C A$ germline mutations, is well known to increase the risk of breast cancer (7); however, it is not equally clear whether deficiency in NHEJ pathway can also increase breast cancer risk (8).

$\mathrm{Ku}$ is a heterodimer consisting of Ku 80 encoded by XRCC5 and Ku70 encoded by XRCC6. Ku recognizes DNA double-strand break ends to initiate the NHEJ pathway, and Ku can also affect the function of the HR pathway by interacting with BRCA1 (9-13). Deletion of XRCC5 in mice leads to increased chromosomal instability, immune deficiency, growth retardation, and cancer $(14,15)$. Altered expression of XRCC5 promotes oncogenic phenotypes, including hyper proliferation and resistance to apoptosis, genomic instability, and tumorigenesis (16), and has been observed in various types of sporadic cancer, including bladder, breast, colorectal, skin, esophageal, gastric, head, and neck cancer (17-22).

Variable number tandem repeats (VNTRs) are tandem repeat DNA sequences often located in gene regulatory regions that can influence gene expression (23-25). VNTRs follow a Mendelian pattern of inheritance. The XRCC5 promoter contains a VNTR at $-160 \mathrm{bp}$, with a 21-bp repetitive unit (TGCGCATGCTCGGCGGGAATC) hosting a putative Sp1binding site (26). Studies in Chinese and Iranian populations have demonstrated the presence of VNTR alleles ranging from 0 to 321 -bp tandem repeats $(0 R, 1 R, 2 R$, and $3 R)$, with individual genotypes of $0 \mathrm{R} / 0 \mathrm{R}, 1 \mathrm{R} / 0 \mathrm{R}, 1 \mathrm{R} / 1 \mathrm{R}, 2 \mathrm{R} / 0 \mathrm{R}, 2 \mathrm{R} / 1 \mathrm{R}, 2 \mathrm{R} / 2 \mathrm{R}, 3 \mathrm{R} / 0 \mathrm{R}$, $3 R / 1 R$, and $3 R / 2 R(22,23)$. Experimental data indicate that the number of VNTR repeats is inversely related to XRCC5 expression, with an increase in the number of VNTR repeats linked to decreased XRCC5 expression (27-29) (Figure 1A). VNTR polymorphisms in the XRCC5 promoter are associated with sporadic bladder, gastric, and breast cancer (30-32).

Given the transmission pattern of VNTR, the uncertainty regarding the role of NHEJ in familial breast cancer, the presence of VNTR polymorphisms in the XRCC5 promoter, and the association of VNTR polymorphisms with sporadic cancer, we hypothesized that VNTR in the XRCC5 promoter could be involved in familial breast cancer. Therefore, we screened germline VNTR polymorphisms in the XRCC5 promoter in three types of familial breast cancer $\left(B R C A 1^{+}, B R C A 2^{+}\right.$, and $\left.B R C A x\right)$. The results showed that certain genotypes of VNTR polymorphisms are associated with the risk of familial breast cancer in $B R C A 1^{+}$ and $B R C A 2^{+}$carriers.

\section{MATERIALS AND METHODS}

\section{Study Population}

The familial breast cancer cases used in this study included three subtypes: familial breast cancer with $B R C A 1$ mutation $\left(B R C A 1^{+}\right)$, familial breast cancer with $B R C A 2$ mutation $\left(B R C A 2^{+}\right)$, and familial breast cancer without $B R C A 1$ or $B R C A 2$ mutations $(B R C A x)$. Samples were obtained from the Hereditary Cancer Center at Creighton University (Tables S1-S3 in Supplementary Material). Healthy control samples of age- and gender-matched, de-identified Caucasian individuals were obtained from the Nebraska Biobank of the University of Nebraska Medical Center and The Nebraska Medical Center. The use of patient samples for this study was approved by the Institutional Review Board of Creighton University School of Medicine (00-12265) and of the University of Nebraska Medical Center (718-11-EP). Written and informed consent to participate in the study and to publicate the results was obtained from all subjects.

\section{Genotyping VNTR Polymorphisms in the XRCC5 Promoter}

PCR amplification, PAGE gel separation, and Sanger sequencing were used to determine VNTR genotype in the XRCC5 promoter of each patient. PCR primer sequences were based on a previously published study (22) with sense primer 5'AGGCGGCTCAAACACCACAC3' and antisense primer 5'CAAGCGGCAGATAGCGGAAAG3'. The PCR mixture consisted of DNA (20 ng), sense and antisense primers (10 pmol), and GoTaqH DNA polymerase (2 U, Promega). The PCR cycling conditions were $7 \mathrm{~min}$ at $95^{\circ} \mathrm{C} ; 35$ cycles of $30 \mathrm{~s}$ at $95^{\circ} \mathrm{C}, 30 \mathrm{~s}$ at $62^{\circ} \mathrm{C}$, and $45 \mathrm{~s}$ at $72^{\circ} \mathrm{C}$; and a final extension of $7 \mathrm{~min}$ at $72^{\circ} \mathrm{C}$. An $8 \%$ PAGE gel was used to separate PCR products to determine allele type and genotype in each case ( $3 \mathrm{R}$ allele $=287 \mathrm{bp}$; $2 \mathrm{R}$ allele $=266 \mathrm{bp} ; 1 \mathrm{R}$ allele $=245 \mathrm{bp}$; and $0 \mathrm{R}$ allele $=224 \mathrm{bp}$ ). Representative products were isolated from PAGE gels and validated by Sanger sequencing.

\section{VNTR Genotypes in the XRCC5 Promoter of Caucasians}

Data from Iranian and Chinese healthy populations showed that VNTR genotypes in the XRCC5 promoter can vary between ethnic groups $(27,28)$. To determine whether the data from 


\section{A VNTR in XRCC5 promoter}

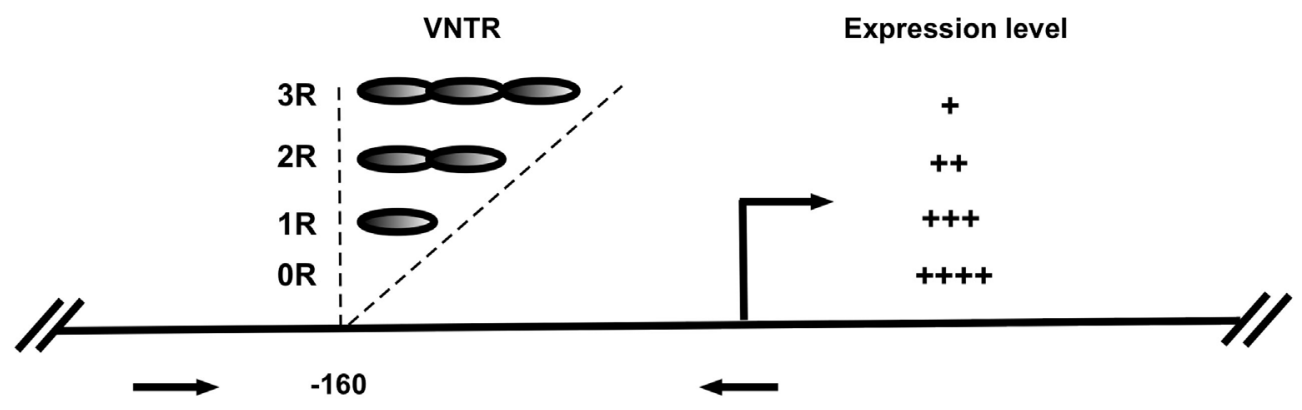

B VNTR genotype shown in PAGE gel

\section{Genotype}

2R/2R 1R/1R 2R/1R 1R/0R 3R/1R 2R/OR 3R/2R

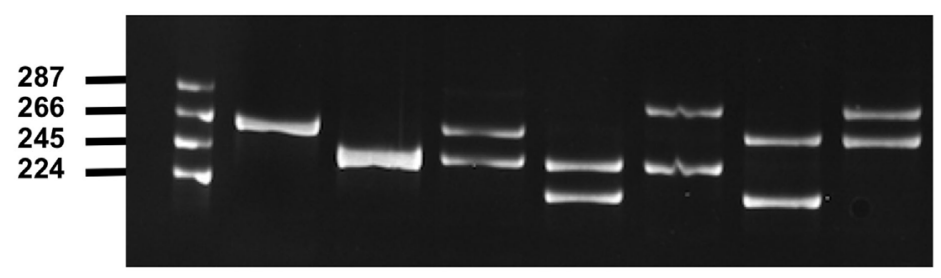

C VNTR shown by Sanger sequencing

$1 R$

AATGGAGAGAAT TGCGCATGCT CGGCGGGAATC GCGCATGCT CGGAGAGAATCT

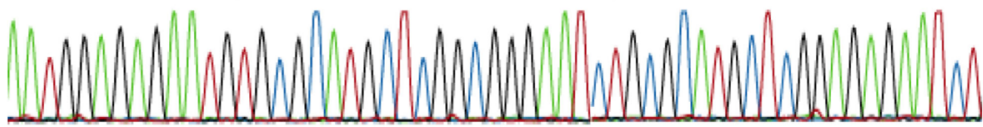

2R

¿AATGGAGAGAAT GGCGCATGCTCGGCGGGAAT CTGCGCATGCTCGGCGGGAATCT GCGCATGCT CGGAGAGAATCT

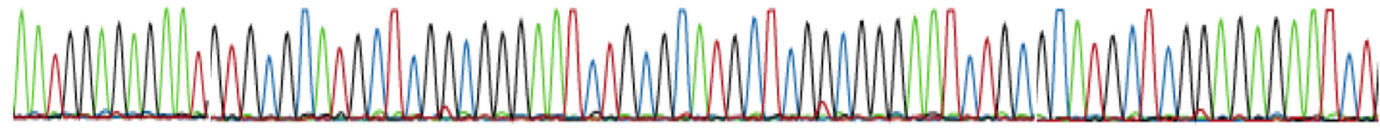

FIGURE 1 | VNTR in XRCC5 promoter. (A) VNTR types and position in the promoter of XRCC5. The VNTR is located at $-160 \mathrm{bp}$, with $3 R, 2 R, 1 R$, and $0 R$ alleles. Arrows refer to PCR primers used to amplify the VNTR region for genotyping. It also shows higher copies of VNTR lead to lower XRCC5 expression (21-23). (B) Size distribution of different VNTR genotypes. PCR products of different genotypes were separated on an $8 \%$ PAGE gel. 2R/2R and 1R/1R had single band, other were heterozygotes with two bands, of which 2R/1R, 1R/0R, and 3R/2R had 21-base differences, and 3R/1R and 2R/0R had 42-base differences; (C) Sanger sequencing validation of $1 R / 1 R$ and $2 R / 2 R$ genotypes. It shows the 21-base unit (TGCGCATGCTCGGCGGGAATC) in 1R, and 42-base unit in 2R. 3R/3R DNA was not available for sequencing due to its rarity in human population.

these healthy populations can be used as suitable healthy controls for our study in breast cancer of Caucasian cases, we tested the genotypes of 100 healthy local Caucasian individuals and compared these with the genotypes from 535 Caucasian Iranian and 235 Chinese populations (27). The results showed no significant difference in genotypes between the local and Iranian Caucasian populations $(P=0.3774)$ with $2 \mathrm{R} / 2 \mathrm{R}, 2 \mathrm{R} / 1 \mathrm{R}$, and $1 \mathrm{R} / 1 \mathrm{R}$ as the major genotypes, but a significant difference was seen in the genotypes between local Caucasian and Chinese populations $(P<0.0001)$, and Iranian Caucasian and Chinese $(P<0.0001)$, whose genotypes included $2 \mathrm{R} / 2 \mathrm{R}, 2 \mathrm{R} / 1 \mathrm{R}, 2 \mathrm{R} / 0 \mathrm{R}, 1 \mathrm{R} / 1 \mathrm{R}, 1 \mathrm{R} / 0 \mathrm{R}$, and 0R/0R (Table 1). The 535 Iranian cases were from a Caucasian population living in the Fars province of Iran (27). Because these Iranian cases and our local cases were of the same ethnicity and 
TABLE 1 | Genotype distribution in three ethnical populations.

\begin{tabular}{lccc}
\hline Genotype & Local & Iranian & Chinese \\
\hline $3 R / 2 R$ & $0(0)$ & $4(1)$ & $0(0)$ \\
$3 R / 1 R$ & $1(1)$ & $8(1)$ & $0(0)$ \\
$3 R / 0 R$ & $1(1)$ & $1(0)$ & $0(0)$ \\
$2 R / 2 R$ & $16(16)$ & $84(16)$ & $28(12)$ \\
$2 R / 1 R$ & $50(50)$ & $205(38)$ & $57(24)$ \\
$2 R / 0 R$ & $5(5)$ & $29(5)$ & $71(30)$ \\
$1 R / 1 R$ & $22(22)$ & $168(31)$ & $12(5)$ \\
1R/OR & $5(5)$ & $33(6)$ & $37(16)$ \\
OR/OR & $0(0)$ & $3(1)$ & $30(13)$ \\
Total & $100(100)$ & $535(100)$ & $235(100)$ \\
\hline$P$ value & Local to Iranian: 0.3774 & \\
& Local to Chinese: $<0.0001$ & \\
& Iranian to Chinese: $<0.0001$ &
\end{tabular}

there were no significant differences in genotypes between the two groups, the genotypes of the 100 local cases and the 535 Iranian cases were combined to make up the control population for downstream analyses. The combined control group is at Hardy-Weinberg equilibrium $\left(X^{2}=4.3485, \mathrm{df}=6, P=0.6296\right)$.

\section{Statistical Analyses}

Fisher's exact test was applied to determine the differences of VNTR polymorphism between the groups of familial breast cancer populations and control population, each type of breast cancer and cancer-affected and -unaffected subgroups within each type of cancer. Both odds ratios and their $95 \%$ confidence intervals and $P$-values were computed by using exact methods to keep consistency (33). Benjamini and Hochberg method was used to control the false positive rate at 0.05 (34). Analyses were performed using $\mathrm{SAS}^{\circledR}$ software version 9.4 (SAS Institute Inc., Cary, NC, USA).

\section{RESULTS}

\section{Samples Used in the Study}

$B R C A 1^{+}$carrier refers to the women who tested positive for a pathogenic $B R C A 1$ mutation; $B R C A 2^{+}$refers to the women who tested positive for a pathogenic BRCA2 mutation; and BRCAx refers to the women who tested negative for the mutations in $B R C A 1, B R C A 2$, and $p 53$, with two or more first or second degree relatives affected with primary in situ or invasive breast, ovarian, fallopian tube, or peritoneal cancer, and at least one person must have negative test result. Under each group, the cases were further divided into breast cancer (ovarian cancer)-affected and - unaffected carriers. The average ages at breast cancer diagnosis among the groups were $41.4\left(B R C A 1^{+}\right), 43.6\left(B R C A 2^{+}\right)$, and 47.7 $(B R C A x)$. The age distributions are consistent with existing data that $B R C A 1$ and $B R C A 2$ mutation carriers tend to suffer cancer at earlier age. Most of the breast cancers were ductal type and ER-positive; all, but one, of the cases of ovarian cancer were invasive at diagnosis (Table 2).

\section{VNTR Genotypes in the XRCC5 Promoter}

The four VNTRalleles in the XRCC5 promoter consist of three 21-bp (TGCGCATGCTCGGCGGGAATC) tandem repeats (3R), two
TABLE 2 | Summary of the $B R C A 1^{+}, B R C A 2^{+}$, and $B R C A x$ carriers used in the study*.

\begin{tabular}{|c|c|c|c|}
\hline Items & $B R C A 1^{+}$ & $\mathrm{BRCA2}^{+}$ & $B R C A x$ \\
\hline Unaffected cases & 60 & 29 & 11 \\
\hline Average current age & $56.9 \pm 14.4$ & $49.1 \pm 14.4$ & $66.4 \pm 15.8$ \\
\hline Affected cases & 166 & 69 & 89 \\
\hline Average age at diagnosis & $41.4 \pm 10.8$ & $43.6 \pm 10.3$ & $47.7 \pm 12.0$ \\
\hline Proband & 38 & 15 & 62 \\
\hline Non-proband & 128 & 54 & 27 \\
\hline Breast cancer & 166 & 69 & 89 \\
\hline ER & $22(+) 43(-)$ & $17(+) 8(-)$ & $27(+) 6(-)$ \\
\hline Unknown & 101 & 44 & 56 \\
\hline PR & $17(+) 45(-)$ & $15(+) 9(-)$ & $21(+) 9(-)$ \\
\hline Unknown & 104 & 45 & 59 \\
\hline HER2/neu & $4(+) 10(-)$ & $3(+) 4(-)$ & $6(+) 17(-)$ \\
\hline Unknown & 152 & 62 & 66 \\
\hline Lymph nodes & $38(+) 54(-)$ & $16(+) 23(-)$ & 16(+)16(-) \\
\hline Unknown & 74 & 30 & 57 \\
\hline Left & 56 & 17 & 24 \\
\hline Right & 55 & 25 & 27 \\
\hline Bilateral & 40 & 19 & 8 \\
\hline Unknown & 15 & 8 & 30 \\
\hline $\begin{array}{l}\text { Adenocarcinoma not } \\
\text { specified }\end{array}$ & 28 & 7 & 17 \\
\hline Ductual carcinoma & 89 & 43 & 59 \\
\hline Lobular carcinoma & 4 & 4 & 4 \\
\hline Medullary carcinoma & 24 & 3 & \\
\hline Mucoid or colloid carcinoma & & & 3 \\
\hline Unknown & 21 & 12 & 6 \\
\hline Invasive & 148 & 63 & 79 \\
\hline In situ & 5 & 2 & 3 \\
\hline Both invasive and in situ & 6 & 3 & 3 \\
\hline Unknown & 7 & 1 & 4 \\
\hline Ovarian cancer & 21 & 5 & 15 \\
\hline Left & & & 1 \\
\hline Right & 3 & & \\
\hline Bilateral & 4 & 1 & 2 \\
\hline Unknown & 14 & 4 & 12 \\
\hline Fallopian tube & 1 & & 1 \\
\hline Lymph nodes & $7(+) 10(-)$ & $1(+)$ & $2(+) 3(-)$ \\
\hline Unknown & 4 & 4 & 10 \\
\hline Carcinoma, not specified & 3 & & 4 \\
\hline Clear cell adenocarcinoma & 1 & 1 & \\
\hline Papillary adenocarcinoma & 2 & 2 & 1 \\
\hline $\begin{array}{l}\text { Adenocarcinoma } \\
\text { (cystadenocarcinoma) }\end{array}$ & 9 & 1 & 1 \\
\hline $\begin{array}{l}\text { Endometrioid } \\
\text { adenocarcinoma }\end{array}$ & 2 & & \\
\hline $\begin{array}{l}\text { Serous (cyst) } \\
\text { adenocarcinoma }\end{array}$ & 5 & 1 & 3 \\
\hline Dysgerminoma & & & 1 \\
\hline Unknown & 1 & & 5 \\
\hline Invasive & 20 & 5 & 9 \\
\hline In situ & 1 & & 1 \\
\hline Unknown & & & 5 \\
\hline
\end{tabular}

*Some number in categories may not add up to the total due to incompleteness of tested cases.

21 -bp repeats (2R), one 21-bp repeat (1R), or without repeat (0R). The combination of PCR, PAGE, and Sanger sequencing methods provided an effective means to determine VNTR genotypes formed 
by the four alleles. Figure 1B shows the genotypes of homozygotes $(1 \mathrm{R} / 1 \mathrm{R}$ and $2 \mathrm{R} / 2 \mathrm{R})$ and heterozygotes $(3 \mathrm{R} / 2 \mathrm{R}, 3 \mathrm{R} / 1 \mathrm{R}, 2 \mathrm{R} / 1 \mathrm{R}$, $2 R / 0 R$, and $1 R / 0 R$ ), and Figure $1 C$ shows the sequences of the 21 -bp repeats from the homozygotes ( $1 \mathrm{R} / 1 \mathrm{R}$ and $2 \mathrm{R} / 2 \mathrm{R})$.

\section{VNTR Genotype Distribution, BRCA Predisposition, and Cancer Status}

We compared the VNTR genotype distributions in the XRCC5 promoter between three types of familial breast cancer: $B R C A 1^{+}$, $B R C A 2^{+}$, and BRCAx (Tables S1-S3 in Supplementary Material). The results show that the $B R C A 1^{+}$and $B R C A 2^{+}$groups differed significantly from the control group $\left(B R C A 1^{+}\right.$group: $P<0.0001$; $B R C A 2^{+}$group: $P=0.0042$ ), but no difference was observed between the BRCAx groups and control group $(P=0.1308)$ (Table 3). To test whether different VNTR genotype distribution exists relating to disease status, the three types of familial breast cancer were divided into breast cancer-affected and breast cancerunaffected subgroups and further compared each subgroup with the control group. The results show that the differences were only present between the cancer-affected subgroups in both groups of $B R C A 1^{+}$(cancer-affected: $P<0.0001$, cancer-unaffected: $P=0.2216$ ) and $B R C A 2^{+}$(cancer-affected: $P=0.0092$, cancerunaffected: $P=0.2748$ ), but not in BRCAx (cancer-affected: $P=0.4251$, cancer-unaffected: $P=0.5664$ ) (Table 4). These results

\begin{tabular}{|c|c|c|c|c|}
\hline \multirow[t]{2}{*}{ Genotype } & \multirow[t]{2}{*}{ Control } & \multicolumn{3}{|c|}{$\begin{array}{c}\text { Familial } \\
\text { breast cancer }\end{array}$} \\
\hline & & $B R C A 1^{+}$ & $\mathrm{BRCA2}^{+}$ & $B R C A x$ \\
\hline Total & 635 (100) & 226 (100) & 98 (100) & 100 (100) \\
\hline $3 \mathrm{R} / 2 \mathrm{R}$ & $4(1)$ & $0(0)$ & $0(0)$ & $0(0)$ \\
\hline 3R/1R & $9(1)$ & $2(1)$ & $0(0)$ & $0(0)$ \\
\hline 3R/OR & $2(0)$ & $0(0)$ & $0(0)$ & $0(0)$ \\
\hline $2 \mathrm{R} / 2 \mathrm{R}$ & $100(16)$ & $61(27)$ & 27 (28) & 23 (23) \\
\hline 2R/1R & $255(40)$ & $113(50)$ & $51(52)$ & $48(48)$ \\
\hline 2R/OR & $34(5)$ & $4(2)$ & $1(1)$ & $3(3)$ \\
\hline $1 \mathrm{R} / 1 \mathrm{R}$ & 190 (30) & $45(20)$ & 17 (17) & 19 (19) \\
\hline $1 \mathrm{R} / \mathrm{OR}$ & $38(6)$ & $1(0)$ & $2(2)$ & $7(7)$ \\
\hline OR/OR & $3(0)$ & $0(0)$ & $0(0)$ & $0(0)$ \\
\hline$P$ value & & $<0.0001$ & 0.0042 & 0.2185 \\
\hline
\end{tabular}

suggest the presence of association between VNTR genotypes and $B R C A 1$ and BRCA2 mutation carriers affected with breast cancer.

We also compared the genotypes between the affected and unaffected subgroups in each group, and observed no difference in between (Table 5). We also evaluated the relationship between ages at diagnosis and VNTR polymorphism and observed no significant relationship in all three groups (data not shown). Therefore, there is no relationship between age of disease, cancer status, and VNTR polymorphism.

\section{Specific Genotypes Associated with Risk of Familial Breast Cancer}

Through comparing between control, breast cancer-affected and breast cancer-unaffected groups, we tested odds ratio to identify specific genotypes associated with risk of breast cancer (Table 6). Considering that the $3 \mathrm{R}$ and $0 \mathrm{R}$ groups contain only few cases in both control and carrier population, we removed $3 R / 2 R, 3 R / 1 R$, $3 \mathrm{R} / 0 \mathrm{R}, 2 \mathrm{R} / 0 \mathrm{R}$, and $0 \mathrm{R} / 0 \mathrm{R}$ but focused on the $2 \mathrm{R} / 2 \mathrm{R}, 2 \mathrm{R} / 1 \mathrm{R}$, $1 R / 1 R$, and $1 R / 0 R$ as they contributed most of the cases. The results showed that

1. $B R C A 1^{+}$group. $2 \mathrm{R} / 2 \mathrm{R}(\mathrm{OR}=1.94,95 \% \mathrm{CI}=1.26-2.95$, $P=0.0096)$ and $2 \mathrm{R} / 1 \mathrm{R}(\mathrm{OR}=1.58,95 \% \mathrm{CI}=1.11-2.26$, $P=0.0388)$ were associated with increased risk of breast cancer in cancer-affected $B R C A 1^{+}$group, and $1 \mathrm{R} / 1 \mathrm{R}$ $(\mathrm{OR}=0.55,95 \% \mathrm{CI}=0.35-0.84, P=0.0196)$ and $1 \mathrm{R} / 0 \mathrm{R}$ $(\mathrm{OR}=0,95 \% \mathrm{CI}=0-0.29, P=0.0012)$ were associated with the decreased risk in cancer-affected $B R C A 1^{+}$group;

2. $B_{R C A 2^{+}}$group. $2 \mathrm{R} / 1 \mathrm{R}(\mathrm{OR}=1.94,95 \% \mathrm{CI}=1.14-3.32$, $P=0.0242)$ was associated with increased risk in canceraffected $B R C A 2^{+}$group. $2 \mathrm{R} / 2 \mathrm{R}, 1 \mathrm{R} / 1 \mathrm{R}$, and $1 \mathrm{R} / 0 \mathrm{R}$ had no association with the risk in cancer-affected $B R C A 2^{+}$group;

3. BRCAx group. $2 \mathrm{R} / 2 \mathrm{R}, 2 \mathrm{R} / 1 \mathrm{R}, 1 \mathrm{R} / 1 \mathrm{R}$, and $1 \mathrm{R} / 0 \mathrm{R}$ had no association with the risk of breast cancer in breast cancer-affected $B R C A x$ group.

\section{DISCUSSION}

Gene regulatory regions have long been considered a potential source of "missing heritability" in cancer $(35,36)$. Our study provides evidence showing that VNTR polymorphisms in the

TABLE 4 | Genotypes between cancer-affected and unaffected familial breast cancer.

\begin{tabular}{|c|c|c|c|c|c|c|c|}
\hline \multirow[t]{2}{*}{ Genotype } & \multirow[t]{2}{*}{ Control } & \multicolumn{2}{|c|}{$\mathrm{BRCA1}^{+}$} & \multicolumn{2}{|c|}{$\mathrm{BRCA2}^{+}$} & \multicolumn{2}{|c|}{$B R C A x$} \\
\hline & & Cancer & No cancer & Cancer & No cancer & Cancer & No cancer \\
\hline Total & $635(100)$ & 166 (100) & $60(100)$ & $69(100)$ & $29(100)$ & $89(100)$ & $11(100)$ \\
\hline $3 \mathrm{R} / 2 \mathrm{R}$ & $4(1)$ & $0(0)$ & $0(0)$ & $0(0)$ & $0(0)$ & $0(0)$ & $0(0)$ \\
\hline $3 R / 1 R$ & $9(1)$ & $2(1)$ & $0(0)$ & $0(0)$ & $0(0)$ & $0(0)$ & $0(0)$ \\
\hline $3 \mathrm{R} / \mathrm{OR}$ & $2(0)$ & $0(0)$ & $0(0)$ & $0(0)$ & $0(0)$ & $0(0)$ & $0(0)$ \\
\hline $2 \mathrm{R} / 2 \mathrm{R}$ & $100(16)$ & $44(27)$ & 17 (28) & 17 (25) & $10(34)$ & $20(22)$ & $3(27)$ \\
\hline $2 \mathrm{R} / 1 \mathrm{R}$ & $255(40)$ & $85(51)$ & $28(47)$ & $39(57)$ & $12(41)$ & $41(46)$ & $6(64)$ \\
\hline $2 \mathrm{R} / \mathrm{OR}$ & $34(5)$ & $3(2)$ & $1(2)$ & $0(0)$ & 1 (3) & $3(3)$ & $0(0)$ \\
\hline 1R/1R & $190(30)$ & 32 (19) & $13(22)$ & 13 (19) & $4(14)$ & $18(20)$ & $1(9)$ \\
\hline $1 \mathrm{R} / \mathrm{OR}$ & $38(6)$ & $0(0)$ & $1(2)$ & $0(0)$ & $2(7)$ & $7(8)$ & $0(0)$ \\
\hline OR/OR & $3(0)$ & $0(0)$ & $0(0)$ & $0(0)$ & $0(0)$ & $0(0)$ & $0(0)$ \\
\hline$P$ value & & $<0.0001$ & 0.2216 & 0.0092 & 0.2748 & 0.4251 & 0.5664 \\
\hline
\end{tabular}


TABLE 5 | Comparison between affected and unaffected group.

\begin{tabular}{|c|c|c|c|c|c|c|}
\hline Genotype & Affected case & Unaffected case & Odds ratio & $95 \% \mathrm{Cl}$ & $P$-value & Adjusted \\
\hline \multicolumn{7}{|l|}{$\mathrm{BRCA1}^{+}$} \\
\hline $2 \mathrm{R} / 2 \mathrm{R}$ & 45 & 16 & 0.9299 & $0.46-1.96$ & 0.8637 & 0.9422 \\
\hline $2 \mathrm{R} / 1 \mathrm{R}$ & 87 & 26 & 1.265 & $0.66-2.42$ & 0.5403 & 1 \\
\hline $1 \mathrm{R} / 1 \mathrm{R}$ & 32 & 13 & 0.7906 & $0.37-1.79$ & 0.5664 & 1 \\
\hline $1 \mathrm{R} / \mathrm{OR}$ & 0 & 1 & 0 & $0-64.08$ & 0.2522 & 1 \\
\hline \multicolumn{7}{|l|}{$\mathrm{BRCA2}^{+}$} \\
\hline $2 \mathrm{R} / 2 \mathrm{R}$ & 17 & 10 & 0.769 & $0.27-2.26$ & 0.6281 & 0.9422 \\
\hline $2 \mathrm{R} / 1 \mathrm{R}$ & 39 & 12 & 1.8417 & $0.70-4.91$ & 0.1904 & 1 \\
\hline $1 \mathrm{R} / 1 \mathrm{R}$ & 13 & 4 & 1.3929 & $0.38-6.45$ & 0.7707 & 1 \\
\hline $1 \mathrm{R} / \mathrm{OR}$ & 0 & 2 & 0 & $0-1.44$ & 0.0854 & 1 \\
\hline \multicolumn{7}{|l|}{$B R C A x$} \\
\hline $2 \mathrm{R} / 2 \mathrm{R}$ & 20 & 3 & 0.77 & 0.19-3.19 & 0.7118 & 0.9350 \\
\hline $2 \mathrm{R} / 1 \mathrm{R}$ & 41 & 6 & 0.71 & $0.20-2.50$ & 0.5951 & 1 \\
\hline $1 \mathrm{R} / 1 \mathrm{R}$ & 18 & 1 & 2.54 & $0.30-21.12$ & 0.6850 & 1 \\
\hline $1 \mathrm{R} / \mathrm{OR}$ & 7 & 0 & Infinity & 0.23-infinity & 1 & 1 \\
\hline
\end{tabular}

TABLE 6 | Association of VNTR genotypes in XRCC5 promoter with familial breast cancer-affected and -unaffected groups.

\begin{tabular}{|c|c|c|c|c|c|c|c|c|c|c|c|}
\hline Genotype & Control & $\begin{array}{l}\text { Affected } \\
\text { case }\end{array}$ & $\begin{array}{l}\text { Odds } \\
\text { ratio }\end{array}$ & $95 \% \mathrm{Cl}$ & $P$-value & Adjusted & $\begin{array}{c}\text { Unaffected } \\
\text { case }\end{array}$ & $\begin{array}{l}\text { Odds } \\
\text { ratio }\end{array}$ & $95 \% \mathrm{Cl}$ & $P$-value & Adjusted \\
\hline \multicolumn{12}{|l|}{$\mathrm{BRCA1}^{+}$} \\
\hline $2 \mathrm{R} / 2 \mathrm{R}$ & 100 & 45 & 1.94 & $1.26-2.95$ & 0.0016 & 0.0096 & 16 & 2.09 & 1.05-3.97 & 0.0221 & 0.1326 \\
\hline $2 \mathrm{R} / 1 \mathrm{R}$ & 255 & 87 & 1.58 & $1.11-2.26$ & 0.0087 & 0.0388 & 26 & 1.25 & $0.69-2.23$ & 0.3190 & 0.4785 \\
\hline $1 \mathrm{R} / 1 \mathrm{R}$ & 190 & 32 & 0.55 & $0.35-0.84$ & 0.0049 & 0.0196 & 13 & 0.69 & $0.33-1.35$ & 0.2906 & 0.4978 \\
\hline $1 \mathrm{R} / \mathrm{OR}$ & 38 & 0 & 0 & $0-0.29$ & 0.0001 & 0.0012 & 1 & 0.28 & $0.01-1.73$ & 0.2414 & 0.5794 \\
\hline \multicolumn{12}{|l|}{$\mathrm{BRCA2}^{+}$} \\
\hline $2 \mathrm{R} / 2 \mathrm{R}$ & 100 & 17 & 1.75 & $0.97-3.15$ & 0.0865 & 0.1038 & 10 & 2.82 & $1.13-6.58$ & 0.0174 & 0.2088 \\
\hline $2 \mathrm{R} / 1 \mathrm{R}$ & 255 & 39 & 1.94 & $1.14-3.32$ & 0.0101 & 0.0242 & 12 & 1.05 & $0.45-2.38$ & 1 & 1 \\
\hline $1 \mathrm{R} / 1 \mathrm{R}$ & 190 & 13 & 0.54 & $0.27-1.04$ & 0.0680 & 0.0907 & 4 & 0.37 & $0.09-1.11$ & 0.0632 & 0.1896 \\
\hline $1 \mathrm{R} / \mathrm{OR}$ & 38 & 0 & 0 & $0-0.73$ & 0.0427 & 0.0641 & 2 & 1.16 & $0.13-4.93$ & 0.6916 & 0.7545 \\
\hline \multicolumn{12}{|l|}{$B R C A x$} \\
\hline $2 \mathrm{R} / 2 \mathrm{R}$ & 100 & 20 & 1.55 & $0.90-2.67$ & 0.1101 & 1 & 3 & 2.01 & $0.52-7.69$ & 0.3945 & 0.5257 \\
\hline $2 \mathrm{R} / 1 \mathrm{R}$ & 255 & 41 & 1.27 & $0.84-1.82$ & 0.2882 & 0.3096 & 6 & 1.79 & $0.54-5.92$ & 0.3654 & 0.5481 \\
\hline $1 \mathrm{R} / 1 \mathrm{R}$ & 190 & 18 & 0.59 & $0.35-1.02$ & 0.0583 & 0.3168 & 1 & 0.23 & $0.03-1.84$ & 0.1885 & 0.5655 \\
\hline $1 \mathrm{R} / \mathrm{OR}$ & 38 & 7 & 1.34 & $0.58-3.10$ & 0.4913 & 1 & 0 & 0 & $0-4.75$ & 1 & 1 \\
\hline
\end{tabular}

$X R C C 5$ promoter is associated with risk of familial breast cancer with $B R C A 1^{+}$and $B R C A 2^{+}$predisposition. Data from sporadic breast cancer showed that $2 \mathrm{R} / 1 \mathrm{R}$ was not associated $(\mathrm{OR}=1.09$, $95 \% \mathrm{CI}=0.78-1.53, P=0.595)$, but $0 \mathrm{R} / 0 \mathrm{R}$ was associated with the disease $(\mathrm{OR}=9.55,95 \% \mathrm{CI}=1.19-76.6, P=0.034)(31)$. The different results suggest that the association of VNTR polymorphisms in the XRCC5 promoter differs between familial breast cancer and sporadic breast cancer.

For the $B R C A 1^{+}$and $B R C A 2^{+}$groups, the results can be explained by synergistic roles between Ku 80 and BRCA1/BRCA2 in maintaining genome stability through the NHRJ and HR pathways (37-39). Altered expression of Ku80 can disturb the synergy resulting in increased breast cancer risk in $B R C A$ mutation carriers. The results also suggest that genotype $1 \mathrm{R} / 1 \mathrm{R}$ and $1 \mathrm{R} / 0 \mathrm{R}$ can reduce the risk of breast cancer in $B R C A 1^{+}$carriers. Based on current knowledge, it is difficult to relate VNTR polymorphisms to $B R C A x$ familial breast cancer, as genetic predisposition in this heterogeneous group of familial breast cancer remains to be determined. We did not observe a relationship between age at onset of disease, cancer status, and VNTR polymorphism. This could be due to the weaker influence by the VNTR polymorphism compared with that of the BRCA mutation predisposition. Alternatively, it could be due to the limited sample size used in the study, which restricts the statistical power to detect the potential significance. Further studies with larger sample size will help to address the issue.

In summary, our study indicates that $2 \mathrm{R} / 2 \mathrm{R}$ and $2 \mathrm{R} / 1 \mathrm{R}$ were significantly associated with increased risk, and $1 \mathrm{R} / 1 \mathrm{R}$ and $1 \mathrm{R} / 0 \mathrm{R}$ were significantly associated with the decreased risk of $B R C A 1^{+}$ breast cancer, whereas $2 \mathrm{R} / 1 \mathrm{R}$ was significantly associated with the increased risk of $B R C A 2^{+}$breast cancer.

\section{AUTHOR CONTRIBUTIONS}

JC and BD performed the genotyping and Sanger sequencing experiments; YK analyzed the genotyping data; JC and JL 
performed statistical analyses; $\mathrm{CS}, \mathrm{DB}$, and HL recruited breast cancer cases and extracted genomic DNA; and SW designed the study, interpreted the data, and drafted the manuscript. All authors read and approved the final manuscript.

\section{ACKNOWLEDGMENTS}

This study was supported by NIH grant R21CA180008 (SW), the Chinese Scholar Council fellowship (JC), the Charles F. and Mary C. Heider Chair in Cancer Research, and by revenue from Nebraska cigarette taxes awarded to Creighton University by the Nebraska Department of Health and Human Services

\section{REFERENCES}

1. Stratton MR, Rahman N. The emerging landscape of breast cancer susceptibility. Nat Genet (2008) 40:17-22. doi:10.1038/ng.2007.53

2. Hall JM, Lee MK, Newman B, Morrow JE, Anderson LA, Huey B, et al. Linkage of early-onset familial breast cancer to chromosome 17q21. Science (1990) 250:1684-9. doi:10.1126/science.2270482

3. Narod SA, Feunteun J, Lynch HT, Watson P, Conway T, Lynch J, et al. Familial breast-ovarian cancer locus on chromosome 17q12-q23. Lancet (1991) 388:82-3. doi:10.1016/0140-6736(91)90076-2

4. Miki Y, Swensen J, Shattuck-Eidens D, Futreal PA, Harshman K, Tavtigian S, et al. A strong candidate for the breast and ovarian cancer susceptibility gene BRCA1. Science (1994) 266:66-71. doi:10.1126/science.7545954

5. Xu X, Wagner KU, Larson D, Weaver Z, Li C, Ried T, et al. Conditional mutation of Brcal in mammary epithelial cells results in blunted ductal morphogenesis and tumour formation. Nat Genet (1999) 22:37-43. doi:10.1038/8743

6. Kanaar R, Hoeijmakers JH, van Gent DC. Molecular mechanisms of DNA double strand break repair. Trends Cell Biol (1998) 8:483-9. doi:10.1016/ S0962-8924(98)01383-X

7. Rothkamm K, Krüger I, Thompson LH, Löbrich M. Pathways of DNA double-strand break repair during the mammalian cell cycle. Mol Cell Biol (2003) 23:5706-15. doi:10.1128/MCB.23.16.5706-5715.2003

8. Mérel P, Prieur A, Pfeiffer P, Delattre O. Absence of major defects in non-homologous DNA end joining in human breast cancer cell lines. Oncogene (2002) 21:5654-9. doi:10.1038/sj.onc.1205742

9. Difilippantonio MJ, Zhu J, Chen HT, Meffre E, Nussenzweig MC, Max EE, et al. DNA repair protein Ku80 suppresses chromosomal aberrations and malignant transformation. Nature (2000) 404:510-4. doi:10.1038/35006670

10. Couëdel C, Mills KD, Barchi M, Shen L, Olshen A, Johnson RD, et al. Collaboration of homologous recombination and nonhomologous end-joining factors for the survival and integrity of mice and cells. Genes Dev (2004) 18:1293-304. doi:10.1101/gad.1209204

11. Davis AJ, Chen DJ. DNA double strand break repair via non-homologous end-joining. Transl Cancer Res (2013) 2:130-43. doi:10.3978/j. issn.2218-676X.2013.04.02

12. Pierce AJ, Hu P, Han M, Ellis N, Jasin M. Ku DNA end-binding protein modulates homologous repair of double-strand breaks in mammalian cells. Genes Dev (2001) 15:3237-42. doi:10.1101/gad.946401

13. Srivastava M, Nambiar M, Sharma S, Karki SS, Goldsmith G, Hegde M, et al. An inhibitor of nonhomologous end-joining abrogates double-strand break repair and impedes cancer progression. Cell (2012) 151:1474-87. doi:10.1016/j.cell.2012.11.054

14. Gu Y, Seidl KJ, Rathbun GA, Zhu C, Manis JP, van der Stoep N, et al. Growth retardation and leaky SCID phenotype of Ku70-deficient mice. Immunity (1997) 7:653-65. doi:10.1016/S1074-7613(00)80386-6

15. Taccioli GE, Gottlieb TM, Blunt T, Priestley A, Demengeot J, Mizuta R, et al. Ku80: product of the XRCC5 gene and its role in DNA repair and V(D)J recombination. Science (1994) 265:1442-5. doi:10.1126/science.8073286

16. Stark JM, Pierce AJ, Oh J, Pastink A, Jasin M. Genetic steps of mammalian homologous repair with distinct mutagenic consequences. Mol Cell Biol (2004) 24:9305-16. doi:10.1128/MCB.24.21.9305-9316.2004
(HL). The Nebraska Biobank of University of Nebraska Medical Center provided the DNA samples from control individuals; the Hereditary Cancer Center of the Creighton University provided breast cancer samples. Written informed consent was obtained from the patient/participant (delete as appropriate) for publication of their individual details and accompanying images in this manuscript.

\section{SUPPLEMENTARY MATERIAL}

The Supplementary Material for this article can be found online at http://journal.frontiersin.org/article/10.3389/fonc.2016.00092

17. Gullo C, Au M, Feng G, Teoh G. The biology of Ku and its potential oncogenic role in cancer. Biochim Biophys Acta (2006) 1765:223-34. doi:10.1016/j. bbcan.2006.01.001

18. Lim JW, Kim H, Kim KH. Expression of Ku70 and Ku80 mediated by NF-kappa B and cyclooxygenase-2 is related to proliferation of human gastric cancer cells. J Biol Chem (2002) 277:46093-100. doi:10.1074/jbc.M206603200

19. Chang HW, Kim SY, Yi SL, Son SH, Song do Y, Moon SY, et al. Expression of Ku 80 correlates with sensitivities to radiation in cancer cell lines of the head and neck. Oral Oncol (2006) 42:979-86. doi:10.1016/j.oraloncology.2005.12.016

20. Pucci S, Mazzarelli P, Rabitti C, Giai M, Gallucci M, Flammia G, et al. Tumor specific modulation of KU70/80 DNA binding activity in breast and bladder human tumor biopsies. Oncogene (2001) 20:739-47. doi:10.1038/ sj.onc. 1204148

21. Mazzarelli P, Parrella P, Seripa D, Signori E, Perrone G, Rabitti C, et al. DNA end binding activity and Ku70/80 heterodimer expression in human colorectal tumor. World J Gastroenterol (2005) 11:6694-700. doi:10.3748/wjg. v11.i42.6694

22. Alshareeda AT, Negm OH, Albarakati N, Green AR, Nolan C, Sultana R, et al. Clinicopathological significance of KU70/KU80, a key DNA damage repair protein in breast cancer. Breast Cancer Res Treat (2013) 139:301-10. doi:10.1007/s10549-013-2542-x

23. Nakamura Y, Koyama K, Matsushima M. VNTR (variable number of tandem repeat) sequences as transcriptional, translational, or functional regulators. J Hum Genet (1998) 43:149-52. doi:10.1007/s100380050059

24. Brookes KJ. The VNTR in complex disorders: the forgotten polymorphisms? A functional way forward? Genomics (2013) 101:273-81. doi:10.1016/j. ygeno.2013.03.003

25. Gymrek M, Willems T, Guilmatre A, Zeng H, Markus B, Georgiev S, et al. Abundant contribution of short tandem repeats to gene expression variation in humans. Nat Genet (2016) 48(1):22-9. doi:10.1038/ng.3461

26. Ludwig DL, Chen F, Peterson SR, Nussenzweig A, Li GC, Chen DJ. Ku80 gene expression is Spl-dependent and sensitive to $\mathrm{CpG}$ methylation within a novel cis element. Gene (1997) 199:181-94. doi:10.1016/S0378-1119(97)00366-1

27. Wang S, Wang M, Yin S, Fu G, Li C, Chen R, et al. A novel variable number of tandem repeats (VNTR) polymorphism containing Sp1 binding elements in the promoter of XRCC5 is a risk factor for human bladder cancer. Mutat Res (2008) 638:26-36. doi:10.1016/j.mrfmmm.2007.08.011

28. Rajaei M, Saadat I, Saadat M. Introducing a novel allele for the polymorphism of variable number of tandem repeats in the promoter region of XRCC5. Biochem Biophys Res Commun (2012) 427:503-5. doi:10.1016/j. bbrc.2012.09.085

29. Rajaei M, Saadat I, Saadat M. The novel allele (3R) of the VNTR polymorphism in the XRCC5 promoter region dramatically decreases the gene expression. Biochem Biophys Res Commun (2013) 430:640-1. doi:10.1016/j. bbrc.2012.11.099

30. Saadat M, Pashaei S, Amerizade F. Susceptibility to gastric cancer and polymorphisms of insertion/deletion at the intron 3 of the XRCC4 and VNTR at the promoter region of the XRCC5. Pathol Oncol Res (2015) 21:689-93. doi:10.1007/s12253-014-9875-6

31. Monsees GM, Kraft P, Chanock SJ, Hunter DJ, Han J. Comprehensive screen of genetic variation in DNA repair pathway genes and postmenopausal 
breast cancer risk. Breast Cancer Res Treat (2011) 125:207-14. doi:10.1007/ s10549-010-0947-3

32. Rajaei M, Saadat I, Omidvari S, Saadat M. Association between polymorphisms at promoters of XRCC5 and XRCC6 genes and risk of breast cancer. Med Oncol (2014) 31:885. doi:10.1007/s12032-014-0885-8

33. Agresti A. Categorical Data Analysis. 3rd ed. Hoboken, NJ: John Willey \& Sons (2013).

34. Benjamini $Y$, Hochberg Y. Controlling the false discovery rate: a practical and powerful approach to multiple testing. J R Stat Soc Series B Stat Methodol (1995) 57:289-300.

35. Maurano MT, Humbert R, Rynes E, Thurman RE, Haugen E, Wang H, et al. Systematic localization of common disease-associated variation in regulatory DNA. Science (2012) 337:1190-5. doi:10.1126/science.1222794

36. Weinhold N, Jacobsen A, Schultz N, Sander C, Lee W. Genome-wide analysis of noncoding regulatory mutations in cancer. Nat Genet (2014) 46:1160-5. doi:10.1038/ng.3101

37. Wei L, Lan L, Hong Z, Yasui A, Ishioka C, Chiba N. Rapid recruitment of BRCA1 to DNA double-strand breaks is dependent on its association with Ku80. Mol Cell Biol (2008) 28:7380-93. doi:10.1128/ MCB.01075-08
38. Jiang G, Plo I, Wang T, Rahman M, Cho JH, Yang E, et al. BRCA1-Ku80 protein interaction enhances end-joining fidelity of chromosomal double-strand breaks in the G1 phase of the cell cycle. J Biol Chem (2013) 288:8966-76. doi:10.1074/jbc.M112.412650

39. Rebbeck TR, Mitra N, Wan F, Sinilnikova OM, Healey S, McGuffog L, et al. Association of type and location of BRCA1 and BRCA2 mutations with risk of breast and ovarian cancer. JAMA (2015) 313:1347-61. doi:10.1001/ jama.2014.5985

Conflict of Interest Statement: The authors declared that the research was conducted in the absence of any commercial and financial relationships that could be constructed as a potential conflict of interest.

Copyright (C) 2016 Cui, Luo, Kim, Snyder, Becirovic, Downs, Lynch and Wang. This is an open-access article distributed under the terms of the Creative Commons Attribution License (CC BY). The use, distribution or reproduction in other forums is permitted, provided the original author(s) or licensor are credited and that the original publication in this journal is cited, in accordance with accepted academic practice. No use, distribution or reproduction is permitted which does not comply with these terms. 